\title{
Syndecan 1 represses cell growth and FSH responsiveness in human granulosa cells
}

\author{
Simon Colombe ${ }^{1}$, Laura Houllier ${ }^{1}$, Emmanuelle Fleurot ${ }^{1}$, Guénaëlle Levallet ${ }^{1,2}$, \\ Annie Benhaïm ${ }^{1,3}$, Pierre-Jacques Bonnamy ${ }^{1}$ and Jérôme Levallet ${ }^{1}$ \\ ${ }^{1}$ Oestrogènes, Reproduction, Cancer, Normandie Université, UNICAEN, Normandie, France, ${ }^{2} \mathrm{CHU}$ de Caen, \\ Service d'Anatomie Pathologique, Caen, France and ${ }^{3} \mathrm{CHU}$ de Caen, Laboratoire de Fécondation In Vitro, Service \\ de Gynécologie Obstétrique, Caen, France \\ Correspondence should be addressed to I Levallet; Email: Jerome.levallet@unicaen.fr
}

\begin{abstract}
Albeit devoid of intrinsic catalytic activity, the transmembrane heparan sulphate proteoglycan syndecan 1 plays critical roles in cellular processes such as extracellular matrix crosstalk, cytoskeletal organization, cell spreading, proliferation and differentiation. During the ovarian cycle, the expression of syndecan 1 in granulosa cells shows cyclic variation suggesting that it might fulfil specific roles in follicle development. To investigate its physiological roles on granulosa cells, syndecan 1 was overexpressed in human granulosa cell line KGN which retains features of granulosa cells from small antral follicle such as estradiol (E2) synthesis and low expression of functional FSH receptor (FSHR). We demonstrated that overexpression of syndecan 1 in immature granulosa cells (KGN-SDC1) induces a profound alteration in their intrinsic characteristics including enhanced spreading and attachment, both associated with a reduced growth rate. Flow cytometry analysis revealed that syndecan 1 overexpression increases the percentage of KGN cells in quiescent phase. This partial cell cycle exit is concordant with downregulated levels of CCND1 and CDK4 and upregulated expression of CDK inhibitor CDKN1A. In parallel both unstimulated and FSH-induced E2 synthesis are reduced in KGN-SDC1 through both repression of CYP19A1 and FSHR mRNA associated with decreased levels of potential regulators NR5A1 and ESR2. Additionally, we provide evidence that transient cAMP accumulation reduction in cells overexpressing syndecan 1 is accompanied by an increase in cAMP-hydrolysing PDE activity. Our results demonstrated that syndecan 1 might regulate differentiation of granulosa cells and follicular development by means of various mechanisms involving morphological changes, control of signalling pathways and alterations in gene expressions.

Free French abstract: A French translation of this abstract is freely available at http://www.reproduction-online.org/ content/153/6/797/suppl/DC2.

Reproduction (2017) $\mathbf{1 5 3} 797-808$
\end{abstract}

\section{Introduction}

Syndecan 1, a member of transmembrane heparan sulphate proteoglycan (HSPG) family composed of four members, is expressed in cell- and tissue-type specific patterns. Composed of three major domains - a short cytoplasmic domain, a membrane-spanning domain and a long extracellular domain bearing heparan sulphate chains - syndecan 1 acts as cell surface receptor, regulating adhesion-dependent signalling pathways during cell growth, migration and differentiation (Bernfield et al. 1999, Couchman 2010). Through binding with the extracellular matrix components (ECM) and/or soluble ligands, syndecan 1 could recruit or tether, near the inner plasma membrane, some scaffolding proteins, thus acting as a regulator of membrane signalling pathways (Couchman 2010). Syndecan 1 can potentiate or inhibit some growth factor/tyrosine kinase receptor interactions through its HS (Bernfield et al. 1999).
Additionally, syndecan 1 might be translocated into the nucleus to modulate transcription factors activities or induce histones post-translational modifications thus modulating the expression of genes (Brockstedt et al. 2002, Szatmari et al. 2012, Kovalszky et al. 2014). Hence, despite the lack of intrinsic catalytic activity, syndecan 1 plays significant roles in cell-cell and cellmatrix adhesion, in regulation of cell growth as well as in differentiation during the developmental processes.

During follicular development, granulosa cells are essential for normal cycle and oocyte development. From the time they enter the selectable stage during the follicular phase, human granulosa cells from preantral follicles express $\mathrm{FSH}$ receptors and become sensitive to cyclic changes of FSH in terms of granulosa cell proliferation (Oktay et al. 1997). A small decrease in $\mathrm{FSH}$ concentration in growing follicles is enough to induce apoptosis of granulosa cells (Chun et al. 1996). 
Ovarian follicles co-ordinately respond to endocrine and paracrine signals in order to mediate maturation of oocytes and cyclic steroid production. Although soluble signalling molecules have been recognized as important factors in follicles growth, development and differentiation, extracellular matrix elements also play a critical role in these functions (Rodgers \& Irving-Rodgers 2010, Woodruff \& Shea 2011). The extracellular matrix has an influence in granulosa cells shape and functions as for instance proliferation, survival as well as expression of steroidogenic enzymes and gonadotrophin receptors (Huet et al. 2001, Berkholtz et al. 2006). General biosynthesis and cellular HSPG distribution in granulosa cells are FSH regulated (Yanagishita et al. 1981, Adashi et al. 1986, Hosseini et al. 1996) and syndecan-1 appeared to be strongly induced in response to the $\mathrm{LH}$ surge in cumulus oocyte complex (COC) but not in mural granulosa cells during oocyte maturation (Watson et al. 2012). In ovarian granulosa cells, syndecan 1 is thus expressed in a temporo-spatial manner (Ishiguro et al. 1999, Oksjoki et al. 1999, Princivalle et al. 2001) suggesting that syndecan 1 fulfils specific roles in the regulation of granulosa cell functions, follicular growth and oocyte maturation (Tsuiki et al. 1988, Sato et al. 1990). These assumptions were corroborated by in vitro experiments showing that deregulation of proteoglycan synthesis could affect FSH-mediated response in rabbit granulosa cells (Benhaim et al. 1995) as well as in rat Sertoli cells (Levallet et al. 2013).

Although syndecan 1 assumes crucial role during early development, SDC1 deficient mice are healthy and fertile (Alexander et al. 2000); this would imply that other syndecans or HSPGs can compensate for the loss of syndecan-1 (Teng et al. 2012). Thus, to investigate the biological functions of syndecan 1 on steroidogenesis and differentiated functions of granulosa cell, syndecan 1 has been overexpressed in a steroidogenic human granulosa-like tumour cell line KGN. The KGN cell line is a metastatic granulosa cell line established from a 73-year-old patient with recurrent, granulosa cell tumour (GCT) in the pelvic region (Nishi et al. 2001). Although KGN cell harbours C402G somatic mutation in a Forkhead transcription factor FOXL2, described in $97 \%$ of adult-type GCTs, these cells retain both proliferative and steroidogenic capacity of normal granulosa cells. The expression of a functional FSH signalling pathway that can stimulate aromatase activity and the absence of $\mathrm{LH}$ response (confirmed by absence of LHCGR expression (Supplementary data)) designated these cells as an immature granulosa cell model of interest to study early follicular development.

\section{Materials and methods}

\section{Materials}

Recombinant FSH was purchased from Merck-Serono (Gonal F-75, Merck-Serono, France). Dulbecco's Modified Eagle
Medium (DMEM), Ham F12 medium, trypsin, FCS (fetal calf serum), pcDNA3.1 Directional TOPO expression kit, Geneticin, Lipofectamine2000, ECL staining kit and Hybond$\mathrm{ECL}$ nitrocellulose membrane were purchased from Life Technologies SAS. $\triangle$ 4-Androstenedione (Androst-4-ene-3,17dione) $[1 \beta-3 \mathrm{H}(\mathrm{N})]$ (AS $26.3 \mathrm{Ci} / \mathrm{mmol}$ ) was purchased from Perkin Elmer. [3H] cAMP Assay Kit (TRK432) was purchased from GE Healthcare (Vélizy-Villacoublay, France). Antityrosine-tubulin antibody, kanamycin, penicillin, peptidase A, streptomycin and mouse anti-tyrosine-tubulin (TUBA) were purchased from Sigma-Aldrich. FSHR (N-20) antibodies, HRP-, TR- and FITC-conjugated secondary antibodies were from Santa Cruz Biotechnology and monoclonal mouse anti-actin (Ab-1) from Millipore SAS. Cell cycle analysis was performed using Coulter DNA-Prep Reagents kit (Beckman Coulter, France). M-MLV-RT, random primers, dNTPs, RNasin, Taq DNA polymerase, GoTaq qPCR Master Mix were purchased from Promega.

\section{Cell culture}

The KGN cell line originated from a Stage III granulosa cell carcinoma removed from a 63-year-old Japanese women in 1984 (Nishi et al. 2001) was obtained from RIKEN Bioresource Center (Tsukuba, Japan). Cells were cultured at $37^{\circ} \mathrm{C}$ under $5 \% \mathrm{CO}_{2}$ atmosphere in Ham F12-Dulbecco's Modified Eagle Medium (HamF12/DMEM, 1/1: v/v (H/D)) containing antibiotics $(50,000 \mathrm{IU} / \mathrm{L}$ penicillin, $50 \mathrm{mg} / \mathrm{L}$ streptomycin and $50 \mathrm{mg} / \mathrm{L}$ kanamycin), fungizone $(0.25 \mathrm{mg} / \mathrm{L})$ and $2.2 \mathrm{~g} / \mathrm{L}$ sodium bicarbonate. The culture medium was supplemented with $10 \%$ $(\mathrm{v} / \mathrm{v})$ fetal calf serum (FCS) as described by Nishi and coworkers. Two or three times a week, when confluence reached $70-80 \%$, the cells were harvested by trypsinization. They were then centrifuged for $5 \mathrm{~min}$ at $400 \mathrm{~g}$ and subjected to experiments or were cultured at $1 \times 10^{4}$ cells $/ \mathrm{cm}^{2}$ in $25 \mathrm{~cm}^{2}$ culture flask. Cells were cultured for at most 10 successive passages during which the properties of the KGN granulosa cells did not undergo significant changes. Human luteinized granulosa cells (LGC) were collected from patients with normal ovulatory function undergoing IVF at the ART unit of the reproductive medicine department of the University Hospital of Caen. All patients gave informed consent before their inclusion in the study. Cells were collected by centrifugation for $10 \mathrm{~min}$ at $300 \mathrm{~g}$, overlaid on Ficoll (PAN Biotech, France) and centrifuged at $600 \mathrm{~g}$ for $5 \mathrm{~min}$ as described in Khalaf and coworkers (Khalaf et al. 2010). Lutein granulosa cells were aspirated from the interface, washed twice and submitted to RNA extraction.

\section{Generation of stably engineered cell lines}

The full length of human syndecan 1 cDNA (933 bp length) was prepared from luteinized human granulosa cells and subcloned into a pcDNA 3.1(+) Directional TOPO Expression vector. The PCR primers were designed based on the full length of mRNA (NM_001006946) with the following sequences: forward primer, 5'CACCATGAGGCGCGCGGCGCTC-3'; reverse primer and 5'-TCAGGCATAGAATTCCTCCTG-3'. The control plasmid was made by inserting into pcDNA 3.1(+) Directional TOPO Expression vector, a 750 bp PCR product provided by supplier that does not contain Kozak sequence 
and ATG codon. Stable transfection of KGN cells was done using Lipofectamine2000 and selected with Geneticin at $400 \mu \mathrm{g} / \mathrm{mL}$ and subsequently grown in HamF12/DMEM-10\% FCS in the presence of Geneticin at $50 \mu \mathrm{g} / \mathrm{mL}$.

\section{Cell growth assays and cell cycle analysis}

Cellular growth was assayed using the crystal violet (CV) staining method with a 24-h interval, over a period of 5 days and after a 24-h adhesion period (starting density of $1 \times 10^{4}$ cells/well in 96-well plates). Cells were washed with PBS and stained with $0.1 \%$ CV. Dye was eluted with $100 \mu \mathrm{L}$ of $10 \%$ acetic acid, and absorbance at $600 \mathrm{~nm}$ was measured using a Metertech $\sum 960$ Microplate reader. For flow cytometry analysis, cells were cultured in HamF12/DMEM-10\% FCS until $70-80 \%$ confluence and harvested with PBS-EDTA containing $0.25 \%$ Trypsin. One million cells were fixed in icecold $75 \%$ ethanol, and stained with propidium iodide (DNAPrep Reagents kit). The cell cycle analysis was carried out using the Gallios Flow Cytometer System and analysed with Kaluza Analysis Software (Beckman Coulter).

\section{Immunofluorescence and microscopy}

The cells were seeded onto a cover glass (3000 cells/12 mm diameter) in HamF12/DMEM-10\% FCS for 24h. Afterward, cells were fixed for $15 \mathrm{~min}$ in $3 \%$ paraformaldehyde and permeabilized with ice-cold $100 \%$ methanol for $10 \mathrm{~min}$ at $-20^{\circ} \mathrm{C}$. Non-specific antigen sites were blocked with PBS$0.3 \%$ Triton X-100 supplemented with 5\% BSA for $1 \mathrm{~h}$ at room temperature and cells were then incubated overnight in a humidified dark chamber at $+4^{\circ} \mathrm{C}$ with polyclonal Syndecan 1 (1:50) or monoclonal anti-tyrosine-tubulin (1:100) antibodies diluted in PBS containing 0.3\% TritonX-100 and $1 \%$ BSA. After primary antibody incubation and washing, the cells were incubated with fluorescent conjugated secondary antibody $(1: 200)$ for $1 \mathrm{~h}$ at room temperature. The coverslips were mounted with UltraCruz mounting medium containing $1.5 \mu \mathrm{g} / \mathrm{mL}$ of $4^{\prime}$,6-diamidino-2-phenylindole (DAPI) for DNA counterstaining and observed by confocal laser scanning microscopy using a FluoView-FV1000, Olympus. Fluorescence signal collection, cell spreading and scaling were performed through the control software (FV10-ASW-1.7, Olympus).

\section{Quantitative and semi-quantitative RT-PCR}

Total RNA was extracted from subconfluent cell cultures using an RNAgents kit. The synthesis of cDNA was performed through reverse transcription of $250 \mathrm{ng}$ RNA using $200 \mathrm{IU}$ M-MLVRT, 20IU RNasin, $0.5 \mu \mathrm{g}$ oligo dT and $100 \mu \mathrm{mol} / \mathrm{L}$ dNTP in a total volume of $20 \mu \mathrm{L}$.

Semi-quantitative RT-PCR was performed with $1.5 \mathrm{IU}$ Taq DNA polymerase in PCR buffer containing $200 \mu \mathrm{mol} / \mathrm{L} \mathrm{dNTP}$, $1.5 \mathrm{mmol} / \mathrm{L} \mathrm{MgCl}_{2}$ and $25 \mathrm{pmol}$ of each primer in a total volume of $25 \mu \mathrm{L}$. The PCR primers used and the size of the resulting PCR products are listed in Supplementary Table 1 (see section on supplementary data given at the end of this article). For semi-quantitative real-time RT-PCR, reverse transcription was made with $250 \mathrm{ng}$ of total RNA in $20 \mu \mathrm{L}$ containing $20 \mathrm{nmol}$ dNTP, $100 \mathrm{ng}$ random primers, $12 \mathrm{IU}$ RNasin and $200 \mathrm{IU}$ M-MLVRT for $1 \mathrm{~h} 30 \mathrm{~min}$ at $37^{\circ} \mathrm{C}$. QPCR was performed in duplicate using an Agilent Technologies Mx3005P real-time PCR machine (Agilent Technologies) and the detection was done by the fluorescent dye SYBRGreen with GoTaq qPCR Master Mix (Promega). Expression levels were calculated according to the $2^{-\Delta \mathrm{Ct}}$ method normalized to the Actin mRNA expression level.

\section{Hormonal assays}

Production of estradiol (E2) and progesterone (P4) were determined in $25-100 \mu \mathrm{L}$ incubation mediums by radioimmunoassay. Cells were seeded at $5 \times 10^{4}$ cells/well in 96-well plates in triplicate and cultured for $48 \mathrm{~h}$ in HamF12/ DMEM-10\% FCS followed by $24 \mathrm{~h}$ in $1 \%$ FCS medium. Cells were incubated for $48 \mathrm{~h}$ with HamF12/DMEM-1\% FCS with or without $100 \mathrm{ng} / \mathrm{mL} \mathrm{rFSH}$. For E2 assay, medium was supplemented with $200 \mathrm{ng} / \mathrm{mL}$ testosterone. Supernatants were collected and stored at $-20^{\circ} \mathrm{C}$ until RIA with specific antibodies (Biosys, Paris antibody, France). Cell number per well was estimated using the crystal violet (CV) method and steroid production expressed as ng of steroids per million cells.

\section{Aromatase assay}

The aromatase activity was determined by measuring the amount of $[3 \mathrm{H}] \mathrm{H}_{2} \mathrm{O}$ released upon the conversion of $[1 \beta-$ $3 \mathrm{H}]$ androstenedione to estrone. Cells were seeded at $15 \times 10^{4}$ cells/well on a 6 -well plate for $48 \mathrm{~h}$ in HamF12/DMEM-10\% FCS then for an additional 24-h period in 1\% FCS containing medium. Cells were further incubated with $42.5 \mathrm{nM}[1 \beta-3 \mathrm{H}]$ androstenedione $(\mathrm{SA}, 26.5 \mathrm{Ci} / \mathrm{mmol})$ for $3 \mathrm{~h}$ at $37^{\circ} \mathrm{C}$. After incubation, the reaction was stopped by the addition of $3 \mathrm{~mL}$ ice-cold chloroform, and the supernatant was centrifuged for $10 \mathrm{~min}$ at $4000 \mathrm{~g}$ to remove precipitated proteins. Aqueous phase was removed $(800 \mu \mathrm{L})$ and combined to $800 \mu \mathrm{L}$ of activated-charcoal (7\%) suspension containing dextran (1.5\%). After $10 \mathrm{~min}$ the charcoal was separated from the aqueous phase by centrifugation $\left(2700 \mathrm{~g}, 15 \mathrm{~min}, 4^{\circ} \mathrm{C}\right)$, and the radioactivity of an aliquot of supernatant was counted by liquid scintillation. The cell protein content was determined after the cell layers were dissolved in $0.1 \mathrm{~mol} / \mathrm{L} \mathrm{NaOH}$ and the aromatase activity was expressed as picomoles per mg of cell protein per hour of incubation.

\section{Cyclic AMP extraction and measurement}

KGN cells were seeded at $12 \times 10^{4}$ cells/well on a 6 -well plate for $48 \mathrm{~h}$ in HamF12/DMEM-10\% FCS and then again for 24 more hours in $1 \%$ FCS containing medium prior to the addition of $\mathrm{FSH}(100 \mathrm{ng} / \mathrm{mL})$ or Forskolin $(1 \mu \mathrm{M})$ for varying times up to $3 \mathrm{~h}$. At the end of incubation, the cultured medium $(1 \mathrm{~mL})$ was collected and cells were scraped with $2 \mathrm{~mL} 100 \%$ ethanol. Then both the medium and cell lysate were pooled and centrifuged $\left(2000 \mathrm{~g}, 15 \mathrm{~min}, 4^{\circ} \mathrm{C}\right)$. Supernatant was collected and evaporated before being resuspended in $200 \mu \mathrm{L}$ Tris $(5 \mathrm{mM}, \mathrm{pH} 7.5)$-EDTA $(4 \mathrm{mM})$. Aliquots of $50 \mu \mathrm{L}$ were assayed for CAMP content using CAMP assay kit following 
manufacturer's instructions ([3H] cAMP Assay Kit (TRK432), GE Healthcare). Total cAMP contents were firstly calculated as $\mathrm{pmol} / \mathrm{well}$ and further corrected by cell number counted from parallels plates to give final values in pmol/cells.

\section{Cell fractions' preparation}

Cultured KGN granulosa cells were washed with cold PBS and were recovered by gentle scraping in lysis buffer (20 mM Tris- $\mathrm{HCl} \mathrm{pH} 7.2,1 \mathrm{mM}$ EDTA, $250 \mathrm{mM}$ sucrose) supplemented with $0.1 \mathrm{mM}$ phenylmethanesulfonyl fluoride, $2 \mathrm{mM}$ benzamidin and a mixture of antiproteases (antipain, aprotinin, leupeptin, pepstatin A) at a final concentration of $1 \mu \mathrm{g} / \mathrm{mL}$ and were centrifuged at $100,000 \mathrm{~g}$ for $1 \mathrm{~h}$ at $4^{\circ} \mathrm{C}$ as previously described (Levallet et al. 2007). The calculation of protein concentration of the samples was done using Bradford method and the supernatant (soluble fraction) and the pellet (particulate fraction) were then stored at $-20^{\circ} \mathrm{C}$.

\section{PDE assay}

Phosphodiesterase activities were assayed according to the Thompson and Appleman two-step procedure (Thompson \& Appleman 1971). Protein mixture $(5-20 \mu \mathrm{g})$ was incubated at $34^{\circ} \mathrm{C}$ for $15 \mathrm{~min}$ in $200 \mu \mathrm{L}$ of reaction buffer $(40 \mathrm{mM}$ Tris- $\mathrm{HCl}$ $\mathrm{pH} 8,1 \mathrm{mMMgCl}$, $1.25 \mathrm{mM} \beta$-mercapto-ethanol, $0.14 \mathrm{mg} \mathrm{BSA}$ ) in the presence of $1 \mu \mathrm{M} \mathrm{CAMP}\left(\left[2,8-{ }^{3} \mathrm{H}\right]\right.$-CAMP $\left.(3.7 \mathrm{kBq} / \mathrm{tube})\right)$. The reaction was then stopped by the addition of $200 \mu \mathrm{L}$ of stop solution (40 mM Tris- $\mathrm{HCl} \mathrm{pH} 7.5,10 \mathrm{mM}$ EDTA) followed by heat denaturation at $100^{\circ} \mathrm{C}$ for $1 \mathrm{~min}$. Crotalus atrox snake venom $(50 \mu \mathrm{g})$ was added to each sample and incubated at $34^{\circ} \mathrm{C}$ for $20 \mathrm{~min}$. The reaction products were separated by anion exchange chromatography using a freshly prepared solution of Dowex (Dowex/water/ethanol: 1/1/1: w/v/v) and an aliquot of supernatant was then counted by liquid scintillation.

\section{Western blot}

Cell fractions were obtained by ultracentrifugation as previously described, the supernatant containied soluble cytosolic proteins and the pellet contained membraneassociated proteins (Levallet et al. 2013). The proteins $(25 \mu \mathrm{g})$ of each subcellular fraction were separated by SDS-PAGE and electroblotted onto a Hybond-ECL nitrocellulose membrane. The membranes were probed with syndecan 1 (C-20) or FSHR (N-20) primary antibodies diluted (1:500) in PBS-Tween, $0.1 \%$ BSA. Membranes were washed and incubated for $1 \mathrm{~h}$ at $4{ }^{\circ} \mathrm{C}$ with HRP-conjugated secondary antibody and revealed with $\mathrm{ECL}$ reagents. Subsequently, densitometric analyses of the bands were semi-quantitatively conducted using TotalLab Image Analysis software (Nonlinear Dynamics Ltd., Newcastle, UK). For loading control, the membranes were stripped and re-probed with mouse anti-actin (Ab-1).

\section{Statistical analysis}

Statistical analysis was carried out using GraphPad Prism software. All experiments were performed at least three times.
Statistical comparisons were performed with Student's t-test when two variables were involved or by one-way analysis of variance (ANOVA) with Tukey's multiple comparison test when appropriate, using the Prism 5 software package (GraphPad Software). A $P$ value of $<0.05$ was considered significant.

\section{Results}

\section{Syndecan 1 overexpression enhances attachment and spreading of $K G N$ cells}

Plasmids containing full length human syndecan 1 (SDC1) cDNA or control (Ctr) sequence were transfected into granulosa cell line KGN to generate through not clonal selection KGN-SDC1 and KGNCtr cell lines respectively. The SDC1 overexpression in $\mathrm{KGN}-\mathrm{SDC1}$, compared with KGN-Ctr and wild type (KGN-WT) cell lines, was confirmed both at mRNA level by semi-quantitative and real-time RT-qPCR and at protein level by western blot and immunofluorescence staining. Interestingly, syndecan 1 expression level obtained in KGN-SDC1 cell line is comparable to those measured in luteinized granulosa cells. Furthermore, it is of note that Syndecan-4 expression level, another member of syndecan family, was not affected by SDC1 overexpression; this suggests the absence of compensatory mechanism between these two syndecans (Supplementary Fig. 1). As shown in Fig. 1A, differences in cell attachment were observed after 30, 60 and $90 \mathrm{~s}$ of trypsin-EDTA treatment between KGN-SDC1 and KGN-Ctr with lower numbers of rounded cells observed in KGN-SDC1 line $(P<0.001$ at respective time). Additionally, using tyrosine-tubulin staining, we observed that cell morphology and cytoskeletal system were affected by syndecan 1 overexpression (Fig. 1B). Unlike KGN control cell lines, displaying a spindle shape at low seeding density with diffuse microtubules structure, KGN-SDC1 cells exhibited increasing spreading with microtubule network, stretching radially from the perinuclear region to the plasma membrane. The morphometric analysis reveals that KGN-SDC1 cells display 3-fold enlarged cytoplasm than KGN control cells (Fig. 1C).

\section{Syndecan 1 overexpression promotes cell cycle exit through cell cycle transcriptional regulation}

Because increased spreading is often associated with alterations in cell growth, we have analysed the growth of KGN cell lines. We demonstrated that cell line expressing high level of syndecan 1 exhibits a significant reduction in growth rate obtained after $72 \mathrm{~h}$ and $96 \mathrm{~h}$ of culture in H/D medium supplemented with $10 \%$ FCS (Fig. 2A) or only after $96 \mathrm{~h}$ in H/D-1\% FCS (not shown). The calculated doubling times revealed that KGNSDC1, cultured in H/D-10\% FCS, needs nearly twice as much time for doubling than control $(52.4 \pm 2.3 \mathrm{~h}$ vs $32.1 \pm 6.5 \mathrm{~h}$ respectively) (Fig. $2 \mathrm{~B}$ ). In line with these 
A

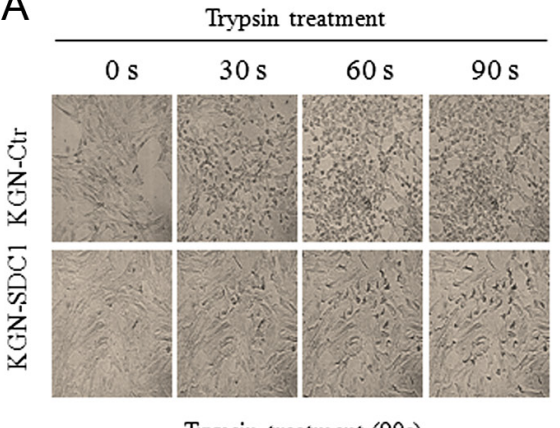

Trypsin treatment (90s)
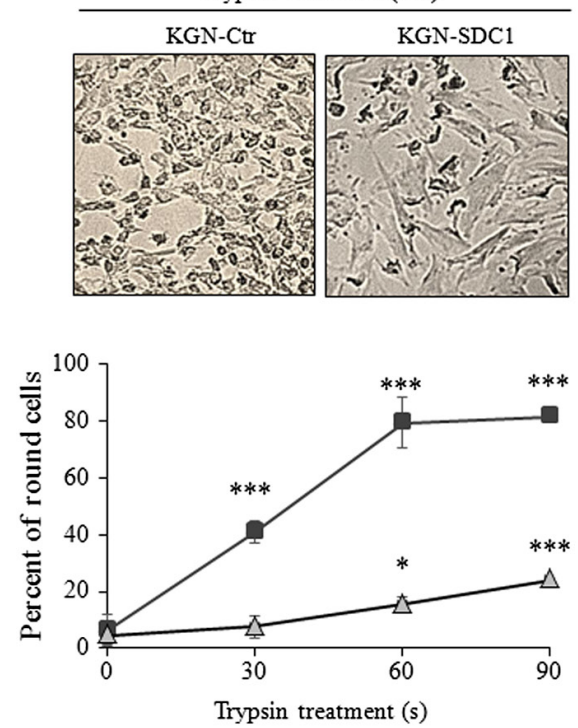

B
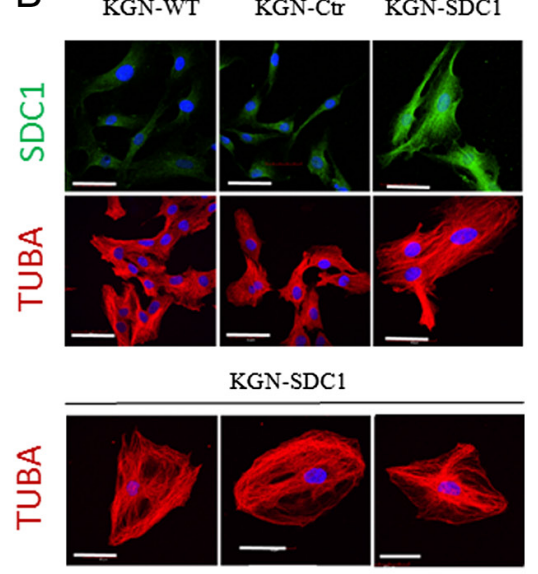

C

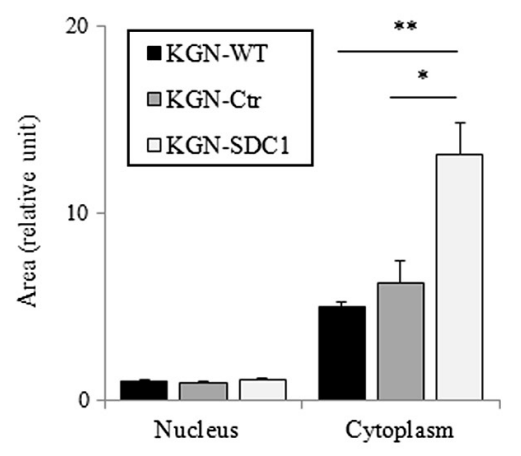

Figure 1 Syndecan 1 overexpression increases the attachment and spreading of granulosa cells. (A) KGN-Ctr and KGN-SDC1 cells were cultured in $10 \%$ FCS culture media until $70-80 \%$ confluence; cell attachment was monitored with phase-contrast light microscope after 30, 60 and $90 \mathrm{~s}$ of trypsintreatment with $0.25 \%(\mathrm{w} / \mathrm{v})$ trypsin in PBS containing $1 \mathrm{mM}$ EDTA. (Magnification $\times 20$ or $\times 40$ for upper and lower panel respectively.) Rounded cells were counted and express as mean \pm S.E.M. of three independent experiments (each performed in duplicate wells with $2-3$ counting/well). ${ }^{*} P<0.05$ and $* * * P<0.001$ vs 0 s for respective cell line. (B) Morphology of growing KGN cell lines observed by immunocytochemistry using anti-SDC1 (SDC1) or anti-tyrosine-tubulin (TUBA) antibodies respectively stain with FITC-labelled and TR-labelled secondary antibodies and counterstained with nuclear dye DAPI. (Scale bar $=50 \mu \mathrm{m}$.) (C) Cell and nucleus areas were measured using FV10ASW-1.7, Olympus software and express as relative unit compared to KGN-WT. Data were means \pm S.E.M. from three independent immunocytochemistry preparation (around 40 individualized cells were analysed). ${ }^{*} P<0.05$; ${ }^{* *} P<0.01$ for cytoplasm area. results, significant accumulation of KGN-SDC1 cells in G0/G1 phases, with a concomitant reduction in G2/M phases, was observed in comparison with the distribution of both KGN-Ctr cells (Fig. 2C and D) or wild type cells (data not shown). Among KGN-SDC1 cells, a significant increase of cells with deficit in DNA content, defined as 'sub-G1' subpopulation, has been observed, but proportion of these cells remains very low (less than $2 \%$ ). The mRNA expression of the cell cycle's main regulators was then estimated by RT-qPCR. In the KGN control cell line (as in KGN-WT (not shown)), a specific expression panel of cyclins (Fig. 3A), cyclin-dependent kinases (Fig. 3B) and CDK inhibitors (Fig. 3C) was observed with CCND1 and CDKN1A having the highest expression levels while the CDKs display comparable levels. Overexpression of SDC1 in KGN cell line was accompanied by a significant reduction of CCND1, CCNE1, CDK4 and CDKN1B gene expression while only CDKN1A expression was found significantly increased.

\section{Syndecan 1 overexpression alters oestrogen synthesis through transcriptional inhibition of CYP19A1}

To investigate involvement of syndecan 1 as a modulator of steroidogenesis in granulosa cells, KGN cells were cultured in $\mathrm{H} / \mathrm{D}$ medium supplemented with only $1 \%$ FCS to minimize cross-reaction with serum components; progesterone (P4) and estradiol (E2) levels were measured in medium after $48 \mathrm{~h}$ of culture. Secreted progesterone levels were similar (around $3 \mathrm{ng} / 10^{6}$ cells) into culture medium of wild type KGN or in both transfected cell lines (Fig. 4A). However, estradiol production by KGN-SDC1 cells was significantly reduced $\left(3.4 \pm 1.6 \mathrm{ng} / 10^{6}\right.$ cells $)$ as compared to levels measured in parental or control KGN cells medium $\left(11.7 \pm 3.5\right.$ and $10.1 \pm 2.3 \mathrm{ng} / 10^{6}$ cells respectively) (Fig. 4B). In agreement, both cytochrome P450 aromatase activity (Fig. 4C) and CYP19A1 mRNA expression (Fig. 4D) were reduced in $\mathrm{KGN}-\mathrm{SDC} 1$ cells respectively by 5 - and 20 -fold as compared to the control cell lines. The expression of other key enzymes involved in P4 and E2 synthesis were also analysed. As shown in Fig. 4E, the cholesterol sidechain cleavage enzyme, encoded by the CYP11A1 gene, which initiates steroidogenesis by converting cholesterol to pregnenolone, was also found downregulated by syndecan 1 while steroidogenic acute regulatory protein (STAR) and 3beta-hydroxysteroid dehydrogenase/delta5delta4 isomerase (HSD3B2) remained unaffected. Additionally, the expression of transcriptional regulators of genes encoding steroidogenic enzymes including NR5A1 $(-50 \%)$ or ESR2 $(-83 \%)$ was significantly 



reduced in KGN-SDC1. No significant differences were found for oestrogen receptors alpha (ESR1) but a decrease in $P G R$ expression has been noticed. In our experimental conditions, and in agreement with Nishi and coworkers observations, luteinizing hormone/ choriogonadotrophin receptor (LHCGR) expression could be evidenced neither in wild type KGN nor in transfected KGN cell lines.

\section{Syndecan 1 suppresses FSH-mediated estradiol synthesis and forskolin-dependent cAMP accumulation}

During follicular development, FSH enhances estradiol biosynthesis through the classical signalling cascade activated by binding $\mathrm{FSH}$ to its receptor (FSHR) and adenylyl cyclase (AC)/cAMP/protein kinase A (PKA) pathway. To go further into the consequences of syndecan 1 overexpression, the $\mathrm{FSH}$ signalling pathway was directly investigated by the addition of $\mathrm{FSH}$ or by bypassing FSHR step using the adenylate cyclase activator forskolin $(10 \mu \mathrm{M})$ or the dbcAMP $(1 \mathrm{mM})$, a non-hydrolysable analogue of cAMP. To preserve their sensitivity to hormone stimulation, the cells were cultured in a medium containing only $1 \%$ FCS. As shown in Fig. 5A, FSH-induced estradiol secretion was totally abrogated in KGN-SDC1 cells although relatively low in KGN-WT and KGN-Ctr. Consistently, a drastic repression of FSHR mRNA expression was observed
(Fig. 5B) in these cells which is also evidenced at protein level, by a 4-fold reduction of the FSHR band intensity in membrane-associated fraction of KGN-SDC1 cells (Fig. 5C). In contrast, dbcAMP which increases oestrogen production in both control cell lines (Fig. 5A) totally restores this ability in the syndecan-1 overexpressing KGN cells. Unlike dbcAMP, amplitude of forskolininduced E2 production was found reduced in KGNSdc1 cell line, from 10.2- or 9.1-fold respectively in KGN-WT and KGN-Ctr to 3.9-fold in KGN-Sdc1. The difference between forskolin and dbcAMP responses in KGN-SDC1 cells was also observed in term of CYP19A1 mRNA expression (Fig. 5D) as illustrated by a significant reduction of Forskolin inducing factor, as compared to dbcAMP which has not been observed in control cell line.

\section{Overexpression of syndecan-1 reduces forskolin- induced cAMP accumulation and increases the phosphodiesterase activity}

The production of cAMP was measured in KGN cells in response to $\mathrm{FSH}$ and forskolin treatment. As shown in Fig. 6A, a slight but significant 2-fold increase in cAMP production was measured after $3 \mathrm{~h}$ of $\mathrm{FSH}$ treatment in $\mathrm{KGN}-\mathrm{WT}$, while in agreement with reduced FSHR expression; FSH is unable to increase CAMP production in granulosa cells expressing high levels of syndecan 1. 

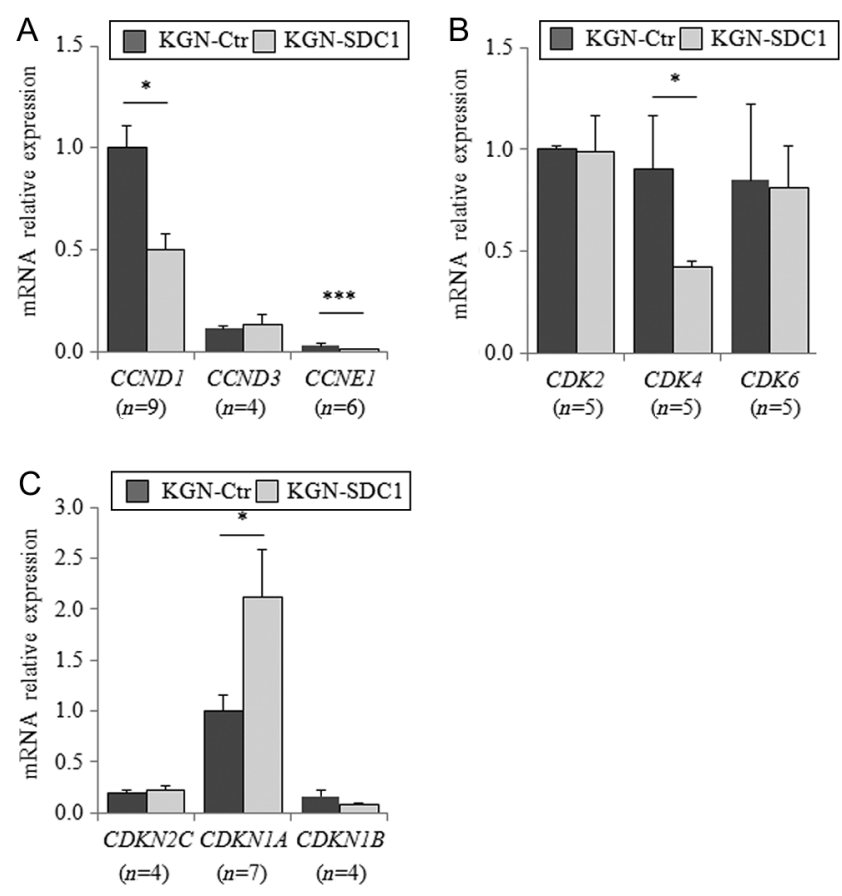

Figure 3 Syndecan 1 overexpression alters expression of cell cycle regulators. Expressions of cyclin (A), cyclin-dependent kinase (B) and their inhibitors $(\mathrm{C})$ were measured by real-time PCR after RNA extraction and reverse transcription from cells cultured in H/D-10\% FCS until $70-80 \%$ confluence. The results were normalized using actin as an internal control, calculated according to $2^{-\Delta \mathrm{Ct}}$ method, and then expressed as relative expression compared to KGN-Ctr $C C N D 1, C D K 2$ and $C D K N 1 A$. Values are means \pm s.E.M. of qRT-PCR from 4 to 9 separate cell cultures. Significantly different at $* P<0.05$; and ${ }^{* * *} P<0.001$ vs KGN-Ctr using Student's $t$-test.

The addition of forskolin, used as adenylate cyclase activator, provokesatime-dependentcAMPaccumulation in KGN-WT cells (Fig. 6B). However, in KGN-SDC1 cell line, in which basal level of cAMP was reduced, forskolin induced only a 3.4-fold accumulation cAMP after $3 \mathrm{~h}$ of treatment corresponding to $70 \%$ reduction of the response intensity as compared to KGN-WT (Fig. 6C). According to the of Thompson and Appleman two-step modified procedure (Thompson \& Appleman 1971), we evaluated cAMP specific phosphodiesterase activity associated either to cytosolic or to membrane compartment of KGN cells (Fig. 6D). In both cytosol and particulate fraction of KGN-SDC1, CAMP-PDE activity was found to be significantly increased as compared to the level measured in KGN-WT cells (2.3- and 2.8fold respectively) thus showing that syndecan 1 might regulate activities of enzymes which catalyse cAMP hydrolysis known as keys regulators of intracellular concentration of this second messenger.

\section{Discussion}

In the present study, we demonstrated that syndecan 1 overexpression in human immature granulosa cells
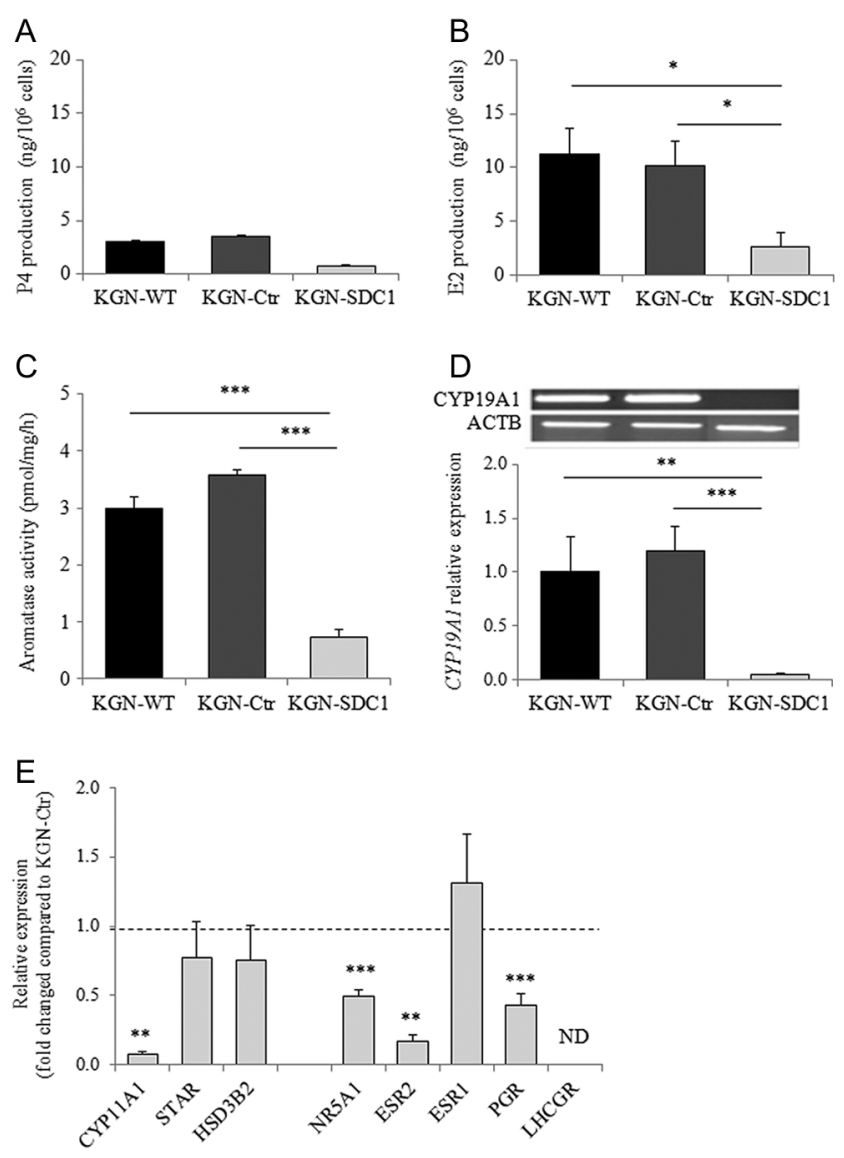

Figure 4 Syndecan 1 overexpression inhibits estradiol synthesis and aromatase expression in KGN cells. (A) Progesterone and (B) estradiol secretion by KGN cells cultured in H/D-1\% FCS supplemented with $200 \mathrm{ng} / \mathrm{mL}$ of testosterone for E2 measurements. Steroids were measured in medium by RIA after $48 \mathrm{~h}$ of culture. The results were the mean \pm S.E.M. of 8 separate triplicate experiments. (C) Aromatase activity was evaluated by measuring tritiated water released by $42.5 \mathrm{nM}(1 \beta-3 \mathrm{H})$ androstenedione for $3 \mathrm{~h}$ at $37^{\circ} \mathrm{C}$ as described in the 'Materials and methods' sections. Values were the mean \pm S.E.M. of three triplicated measurements. (D) Expression of CYP19A1 mRNA was estimated by semi-quantitative (upper panel) and real-time RT-PCR (lower panel). The results were normalized using actin as an internal control and were the mean \pm S.E.M. of qRT-PCR from 10 separated culture. The obtained data were compared to the expression in KGN-Ctr using Student's t-test. **P $P<0.01$ and $* * * P<0.001$.

KGN induces a profound alteration of their intrinsic characteristics such as changes in cell morphology and the expression of genes related to differentiated function of granulosa cell that leads to a reduced growth rate, alteration of FSH signalling and steroidogenesis. Granulosa cells expressing high level of syndecan 1 (KGN-SDC1) exhibited an enlargement of the cytoskeletal network, associated with an increased cell spreading and adhesion. Consistently, through its ability to transmit signals from outer to inner membrane (Hozumi et al. 2010, Ishikawa \& Kramer 2010), syndecan 1-mediated morphological changes were 
also accompanied by a reduced growth rate of $\mathrm{KGN}$ SDC1 cells. Accumulation of KGN cells overexpressing SDC 1 in quiescent phase G0/G1 and the concomitant reduction of cells progressing throughout $\mathrm{S}$ and $\mathrm{G} 2 / \mathrm{M}$ phases is in line with a downregulation of cyclin D1 (CCND1) and CDK4 expression and an increased level of the cyclin-dependent kinase inhibitor $1 \mathrm{~A}(C D K N 1 \mathrm{~A})$ observed in KGN-SDC1. Involvement of syndecan 1 in cell cycle control and proliferation had already been described (Zong et al. 2010, Ibrahim et al. 2012) as in human granulosa cell tumour, in which a decreased expression of syndecan 1 was observed (Owens et al. 2002). Interestingly, in a human malignant mesothelioma cell line, genes altered by syndecan 1 overexpression belong to cell adhesion and cell cycle regulation, with the majority being downregulated especially those driving the G1 phase and G1/S transition (Szatmari et al. 2012). The cytoplasmic tail of syndecan 1 core protein possesses a nuclear localization signal sequence and a tubulin-dependent translocation of syndecan 1 into the nucleus have been observed (Zong et al. 2011). Nuclear syndecan 1 can interact with transcription factors or histones to regulates the transcriptional machinery and transcription level of target genes (Brockstedt et al. 2002, Chen \& Sanderson 2009, Szatmari \& Dobra 2013, Stewart \& Sanderson 2014).
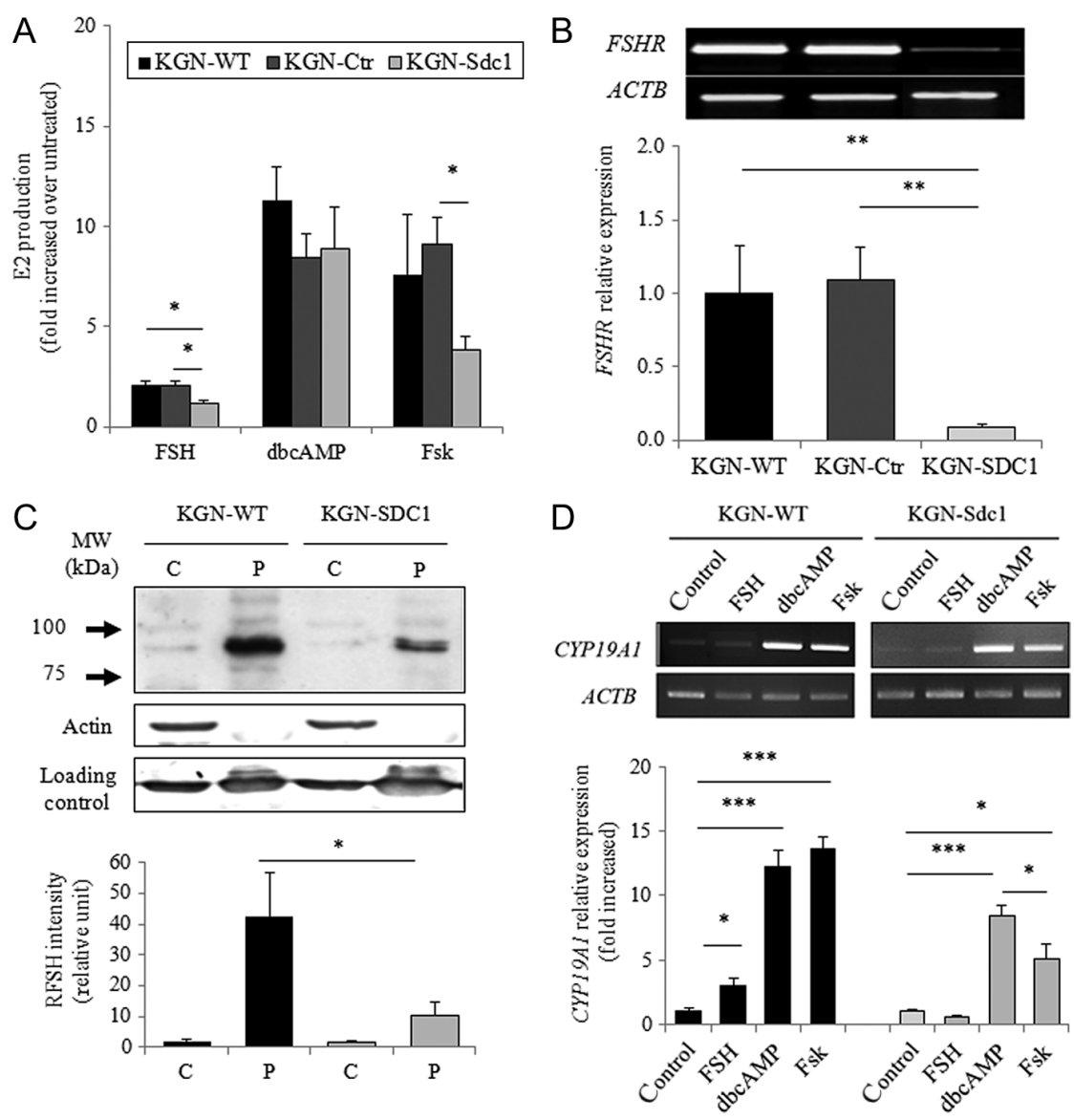

Figure 5 Syndecan 1 overexpression decrease FSH responsiveness through downregulation of FSHR expression. (A) Estradiol production by KGN cells incubated during $48 \mathrm{~h}$ in HamF12/DMEM-1\% FCS medium supplemented with $200 \mathrm{ng} / \mathrm{mL}$ testosterone with or without $100 \mathrm{ng} / \mathrm{mL} \mathrm{rFSH}$, $1 \mathrm{mM}$ dbcAMP or $10 \mu \mathrm{M}$ Forskolin was measured by RIA. Estradiol contents are express as fold induction compared to untreated cells.

Each value indicates the mean \pm S.E.M. of 3 experiments. ${ }^{*} P<0.05$ by one-way analysis of variance (ANOVA) with Tukey's multiple comparison test for each treatment. (B) Expression of FSHR mRNA in KGN cells by semi-quantitative (upper panel) and real-time RT-PCR. The results were normalized using actin as an internal control and were the mean \pm S.E.M. of 4 separate experiments performed in duplicate. ${ }^{* * P} P<0.01$.

(C) Expression of FSHR in cytosolic (C) and particulate (P) fractions estimated by Western blot with anti-FSHR antibody and re-probed with mouse anti-actin (Ab-1) to estimated purity of subcellular fraction. FSHR levels were normalized with loading control and densitometry quantification was performed with ImageJ software. The results were the mean \pm S.E.M. of 3 separate experiments. ${ }^{*} P<0.05$ vs KGN-Ctr. (D) Expression of CYP19A1 mRNA in KGN-WT and KGN-Sdc1 cells stimulated with FSH, dbcAMP or Forskolin. Semi-quantitative RT-PCR was performed after $24 \mathrm{~h}$ of treatment (upper panel). Optimal numbers of PCR cycles were adjusted for CYP19A1 in order to quantify the difference in transcripts levels according to cell line. Signals were quantified using Image software, normalized using actin as an internal control and expressed as fold increase over respective control for each cell line. Values are means \pm S.E.M. of 4 separate experiments (lower panel). ${ }^{*} P<0.05$; ${ }^{* * *} P<0.001$ estimated by one-way analysis of variance (ANOVA) with Tukey's multiple comparison test for each cell line. 

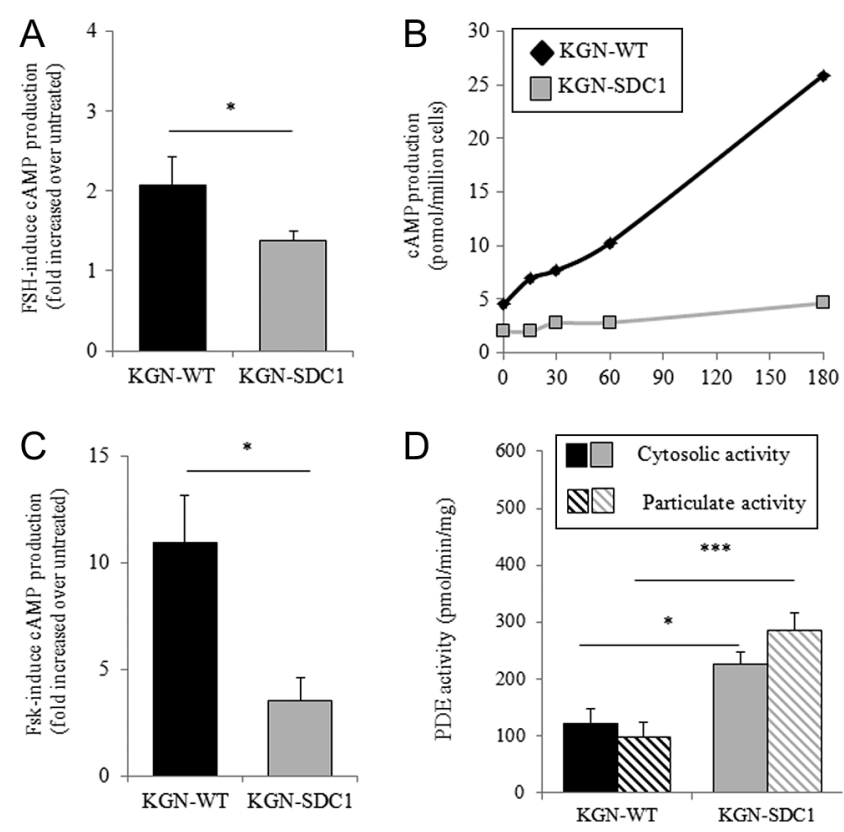

Figure 6 Reduction of Forskolin-dependent cAMP accumulation is associated with increased phosphodiesterase activity in KGN-SDC1 cells. KGN Cells were kept in culture for $24 \mathrm{~h}$ in $1 \%$ FCS containing medium before addition of FSH $(100 \mathrm{ng} / \mathrm{mL})$ or Forskolin $(1 \mu \mathrm{M})$ for increasing period of time. (A) CAMP contents were measured after $3 \mathrm{~h}$ of FSH treatment and expressed as fold-increase vs control from four independent experiments. ${ }^{*} P<0.05$ using $t$-test. (B) Timedependent accumulation of cAMP following Forskolin stimulation measured by [3H]cAMP assay and expressed as pmol/million cells (representative experiment). (C) cAMP contents were measured after $3 \mathrm{~h}$ of Forskolin treatment and expressed as fold increase vs control from four independent experiments. ${ }^{*} P<0.05$ using $t$-test. (D) CAMP phosphodiesterase activities in particulate (filled bar) and cytosolic (hatched bar) proteins fractions were measured as described in the material and methods section by incubating proteins with [2,8-3H]-cAMP. The determined PDE activity was expressed as pmoles of cAMP hydrolyzed per min and per mg protein. Values were means \pm S.E.M. of four independent experiments performed in triplicate. ${ }^{* *} P<0.01 ;{ }^{* * *} P<0.001$ estimated by one-way analysis of variance (ANOVA) with Tukey's multiple comparison test.

We also demonstrate, in this study, that syndecan 1 overexpression deeply affects granulosa cell steroidogenesis. The relationships between cell shape and function (Gutierrez et al. 1997) or cell polarization and steroid production/secretion have been demonstrated in vitro in granulosa cell (Lawrence et al. 1979) and the involvement of glycosaminoglycans was suggested (Huet et al. 2001). We provided evidence that the expression of high level of syndecan 1 in granulosa cells drastically reduces basal and FSH-induced estradiol production mainly through transcriptional repression of CYP19A1 and FSHR genes. Besides, the expression of the steroidogenic factor 1 (NR5A1), oestrogen receptor beta (ESR2) and progesterone receptor $(P G R)$, which are all crucial to promote the differentiation of mesenchymal stem cells into steroidogenic cells or to maintain follicular growth and steroidogenesis (Conneely et al. 2002, Hegele-Hartung et al. 2004, Ferraz-de-Souza et al. 2011, Mizutani et al. 2014), were also reduced in KGNSDC1 cells. The presence of a binding site for NR5A1 and ESR2 in the CYP19A1 and FSHR genes promotor (Levallet et al. 2001, Luo \& Wiltbank 2006, Stocco 2008), in addition to downregulation of these transcription factors in KGN-SDC1, further confirms syndecan 1 involvement in oestrogen synthesis regulation and $\mathrm{FSH}$ signalling. In contrast to estradiol production, synthesis and secretion of progesterone were not affected by syndecan 1 overexpression, and among the three enzymes whose expression level reflects progesterone production i.e. STAR, CYP11A1 and HSD3B2 (Mizutani et al. 2015) only CYP11A1 expression was downregulated. These observations suggest that SDC1 regulates a panel of gene activated for definite granulosa cell function at a specific stage of follicle development. Interestingly, in mice, during in vitro maturation, treatment of cultured COCs with heparin, which inhibits HSPG-dependent growth factor signalling, significantly altered the expression of more than 600 genes, including LHCGR and CYP11A1 (Watson et al. 2012).

The results presented in this work brought to light another mechanism by which syndecan 1 may affect granulosa cell function and FSH/CAMP/PKAmediated response. Whether, overexpression of syndecan 1 abrogates FSH response, mainly through transcriptional repression of FSHR, estradiol synthesis, after addition of non-hydrolysable cAMP (dbcAMP) was not affected and measured in comparable range reported previously in KGN cells (Tsutsumi et al. 2008, Nishi et al. 2001). Nevertheless, overexpression of syndecan 1 reduces forskolin-mediated response in terms of cAMP accumulation, CYP19A1 expression and estradiol synthesis. Downstream to membrane signalling complex (FSHR/pG/Adenylate cyclase), the regulation of phosphodiesterases (PDEs) is crucial for the CAMP signal termination (Conti et al. 2002). We previously described, in rat Sertoli cells, that the alterations of proteoglycans synthesis impaired FSHR/G protein coupling, decreased $\mathrm{PDE}$ activity and finally $\mathrm{FSH}$-stimulated estradiol synthesis (Phamantu et al. 1999, Levallet et al. 2007, 2008, 2013). Through their cytoplasmic domain, proteoglycans can associate with a large number of adaptor and signalling molecules including PKA (Hayashida et al. 2006) or phosphodiesterases (Levallet et al. 2007), both involved in intracellular cAMP steady state either by direct interaction with enzyme activity or by promoting scaffolding signalling complexes (Tkachenko et al. 2005, Lambaerts et al. 2009). Thus, the discrepancy between forskolin- and dbcAMP-response as observed in KGNSDC1 cells could be related either to adenylate cyclase activity decreases or CAMP hydrolysis activity increases, both suggesting that syndecan 1 may also affect the intensity, duration and spatial propagation of cAMP signal in granulosa cells. Such regulation is critical 
to activate a specific pattern of gene expression and to assume particular granulosa cell functions such as proliferation or steroidogenesis, and thus differentiation between follicular cumulus and mural granulosa cell (Conti 2002, Park et al. 2003, Hunzicker-Dunn \& Maizels 2006). Interestingly, in granulosa cells, functional activity of PDE (Sasseville et al. 2009) and syndecan 1 expression (Watson et al. 2012) exhibit a change during follicular growth and both drastically increase in cumulus cells. During this transition, FSH enhances, via increasing production of adenosine monophosphate, estradiol biosynthesis together with the expression of proliferation and differentiation genes, including CYP19A1 (Hunzicker-Dunn \& Maizels 2006) and becomes essential to prevent granulosa cell apoptosis and follicular atresia (Chun et al. 1996). The transition from pre-antral to antral follicle was associated with the differentiation of GC into the steroidogenic mural GCs, which lines the follicular wall, critical for steroidogenesis and the cumulus cells that nurse the oocyte by promoting its growth and developmental competence through paracrine action with oocyte-produced factors (Oktay et al. 1997, Edson et al. 2009). Heparan sulphate proteoglycans (HSPGs) are critical modulators of growth factor activities (Huet et al. 2001, Tkachenko et al. 2005) including growth factors which play important roles within the follicular growth and oocytes' maturation such as the insulin-like growth factor, transforming growth factor beta families or fibroblast growth factors (FGFs) (Knight \& Glister 2006, Gilchrist et al. 2008, Price 2016). Thus the variation of SDC1 expression or of subcellular location (Hosseini et al. 1996), by modulating the signalling gradients of growth factors, might regulate follicular development. Additional experiments have to be done to delineate mechanism by which syndecan-1 modulates granulosa cells' functions, but we demonstrated, in the present paper, that overexpression of syndecan 1, reaching a level comparable to those present in luteinized granulosa cells (Supplementary Fig. 1), promotes cell cycle exit, loss of FSH responsiveness and repression of oestrogen synthesis in human granulosa cells. Thus, a low level of syndecan 1 is probably required for the onset of oestrogen production and for the initiation of FSH-mediated follicular growth. Such hypothesis is consistent with the weak level of syndecan 1 expressed by immature granulosa cells (Adashi et al. 1986, Ishiguro et al. 1999, Princivalle et al. 2001, Watson et al. 2012). Consistently, after the LH surge, granulosa cells exit the cell cycle (Quirk et al. 2004) in a timing matching with the peak of syndecan-1 expression (Ishiguro et al. 1999, Oksjoki et al. 1999, Watson et al. 2012). Concomitantly, luteinized granulosa cells lose their proliferative activity, the expression of FSHR and CYP19A1 mRNA as well as estradiol synthesis declines (Sugino 2014).

Extracellular matrix within the follicle plays a critical role in various ovarian cell functions, such as adhesion, migration, survival, differentiation and proliferation, via mechanical and chemical signals (Rodgers \& Irving-Rodgers 2010, Woodruff \& Shea 2011). Through multiple mechanisms involving a dynamic linkage between the ECM and the cytoskeleton, the control of signalling pathways and the alteration of gene expression, syndecan 1 might regulate granulosa cell proliferation and differentiated functions including steroidogenesis and gonadotrophin responsiveness. Thus, the data presented herein demonstrated for the first time that, despite lack of catalytic activity, the ECM receptor syndecan 1 might participate in early ovarian follicular development. In this respect, KGN-SDC1 cell line is a useful cellular model to further investigate the physiological and pathological consequences of syndecan 1 expression in granulosa cells, and the molecular mechanisms involved.

\section{Supplementary data}

This is linked to the online version of the paper at http://dx.doi. org/10.1530/REP-17-0074.

\section{Declaration of interest}

The authors declare that there is no conflict of interest that could be perceived as prejudicing the impartiality of the research reported.

\section{Funding}

This work was supported by the French Ministère de I'Enseignement Supérieur et de la Recherche and by the Institut National de la Recherche Agronomique.

\section{Acknowledgements}

The authors thank D Goux and N Elie from the Centre de Microscopie Appliquée à la Biologie (CMABIO3), University of Caen Normandy. They also thank M Guillamin from the Service Cytométrie of the Centre François Baclesse (BioTICLA). The authors would like to thank C Quint from the 'Carré International', University of Caen Normandy for the proofreading of this manuscript.

\section{References}

Adashi EY, Resnick CE, Svoboda ME, van Wyk JJ, Hascall VC \& Yanagishita M 1986 Independent and synergistic actions of somatomedin- $C$ in the stimulation of proteoglycan biosynthesis by cultured rat granulosa cells. Endocrinology 118 456-458. (doi:10.1210/endo-118-1-456)

Alexander CM, Reichsman F, Hinkes MT, Lincecum J, Becker KA, Cumberledge S \& Bernfield M 2000 Syndecan-1 is required for Wnt-1induced mammary tumorigenesis in mice. Nature Genetics 25 329-332. (doi:10.1038/77108)

Benhaim A, Feral C, Langris M, Bocquet J \& Leymarie P 1995 Progesterone secretion and proliferation in cultured rabbit granulosa cells under conditions of beta-D-xyloside-induced inhibition of proteoglycan 
synthesis. Biology of Reproduction 52 939-946. (doi:10.1095/ biolreprod52.4.939)

Berkholtz CB, Shea LD \& Woodruff TK 2006 Extracellular matrix functions in follicle maturation. Seminars in Reproductive Medicine 24 262-269. (doi:10.1055/s-2006-948555)

Bernfield M, Gotte M, Park PW, Reizes O, Fitzgerald ML, Lincecum J \& Zako M 1999 Functions of cell surface heparan sulfate proteoglycans. Annual Review of Biochemistry 68 729-777. (doi:10.1146/annurev. biochem.68.1.729)

Brockstedt U, Dobra K, Nurminen M \& Hjerpe A 2002 Immunoreactivity to cell surface syndecans in cytoplasm and nucleus: tubulin-dependent rearrangements. Experimental Cell Research 274 235-245. (doi:10.1006/ excr.2002.5477)

Chen L \& Sanderson RD 2009 Heparanase regulates levels of syndecan-1 in the nucleus. PLoS ONE 4 e4947. (doi:10.1371/journal.pone.0004947)

Chun SY, Eisenhauer KM, Minami S, Billig H, Perlas E \& Hsueh AJ 1996 Hormonal regulation of apoptosis in early antral follicles: folliclestimulating hormone as a major survival factor. Endocrinology 137 1447-1456. (doi:10.1210/endo.137.4.8625923)

Conneely OM, Mulac-Jericevic B, DeMayo F, Lydon JP \& O'Malley BW 2002 Reproductive functions of progesterone receptors. Recent Progress in Hormone Research 57 339-355. (doi:10.1210/rp.57.1.339)

Conti M 2002 Specificity of the cyclic adenosine 3',5'-monophosphate signal in granulosa cell function. Biology of Reproduction $\mathbf{6 7}$ 1653-1661. (doi:10.1095/biolreprod.102.004952)

Couchman JR 2010 Transmembrane signaling proteoglycans. Annual Review of Cell and Developmental Biology 26 89-114. (doi:10.1146/ annurev-cellbio-100109-104126)

Edson MA, Nagaraja AK \& Matzuk MM 2009 The mammalian ovary from genesis to revelation. Endocrine Reviews 30 624-712. (doi:10.1210/ er.2009-0012)

Ferraz-de-Souza B, Lin L \& Achermann JC 2011 Steroidogenic factor-1 (SF1, NR5A1) and human disease. Molecular and Cellular Endocrinology 336 198-205. (doi:10.1016/j.mce.2010.11.006)

Gilchrist RB, Lane M \& Thompson JG 2008 Oocyte-secreted factors: regulators of cumulus cell function and oocyte quality. Human Reproduction 14 159-177. (doi:10.1093/humupd/dmm040)

Gutierrez CG, Campbell BK \& Webb R 1997 Development of a longterm bovine granulosa cell culture system: induction and maintenance of estradiol production, response to follicle-stimulating hormone, and morphological characteristics. Biology of Reproduction 56 608-616. (doi:10.1095/biolreprod56.3.608)

Hayashida K, Johnston DR, Goldberger O \& Park PW 2006 Syndecan-1 expression in epithelial cells is induced by transforming growth factor beta through a PKA-dependent pathway. Journal of Biological Chemistry 281 24365-24374. (doi:10.1074/jbc.M509320200)

Hegele-Hartung C, Siebel P, Peters O, Kosemund D, Muller G, Hillisch A, Walter A, Kraetzschmar J \& Fritzemeier KH 2004 Impact of isotypeselective estrogen receptor agonists on ovarian function. PNAS 101 5129-5134. (doi:10.1073/pnas.0306720101)

Hosseini G, Liu J \& de Agostini Al 1996 Characterization and hormonal modulation of anticoagulant heparan sulfate proteoglycans synthesized by rat ovarian granulosa cells. Journal of Biological Chemistry 271 22090-22099. (doi:10.1074/jbc.271.36.22090)

Hozumi K, Kobayashi K, Katagiri F, Kikkawa Y, Kadoya Y \& Nomizu M 2010 Syndecan- and integrin-binding peptides synergistically accelerate cell adhesion. FEBS Letters 584 3381-3385. (doi:10.1016/j. febslet.2010.06.032)

Huet C, Pisselet C, Mandon-Pepin B, Monget P \& Monniaux D 2001 Extracellular matrix regulates ovine granulosa cell survival, proliferation and steroidogenesis: relationships between cell shape and function. Journal of Endocrinology 169 347-360. (doi:10.1677/ joe.0.1690347)

Hunzicker-Dunn M \& Maizels ET 2006 FSH signaling pathways in immature granulosa cells that regulate target gene expression: branching out from protein kinase A. Cell Signaling 18 1351-1359. (doi:10.1016/j. cellsig.2006.02.011)

Ibrahim SA, Yip GW, Stock C, Pan JW, Neubauer C, Poeter M, Pupjalis D, Koo CY, Kelsch R, Schule R et al. 2012 Targeting of syndecan-1 by microRNA miR-10b promotes breast cancer cell motility and invasiveness via a Rho-GTPase- and E-cadherin-dependent mechanism. International Journal of Cancer 131 E884-E896. (doi:10.1002/ijc.27629)
Ishiguro K, Kojima T, Taguchi O, Saito H, Muramatsu T \& Kadomatsu K 1999 Syndecan-4 expression is associated with follicular atresia in mouse ovary. Histochemistry and Cell Biology 112 25-33. (doi:10.1007/ s004180050388)

Ishikawa T \& Kramer RH 2010 Sdc1 negatively modulates carcinoma cell motility and invasion. Experimental Cell Research 316 951-965. (doi:10.1016/j.yexcr.2009.12.013)

Khalaf M, Mittre H, Levallet J, Hanoux V, Denoual C, Herlicoviez M, Bonnamy PJ \& Benhaim A 2010 GnRH agonist and GnRH antagonist protocols in ovarian stimulation: differential regulation pathway of aromatase expression in human granulosa cells. Reproductive BioMedicine Online 21 56-65. (doi:10.1016/j.rbmo.2010.03.017)

Knight PG \& Glister C 2006 TGF-beta superfamily members and ovarian follicle development. Reproduction 132 191-206. (doi:10.1530/ rep.1.01074)

Kovalszky I, Hjerpe A \& Dobra K 2014 Nuclear translocation of heparan sulfate proteoglycans and their functional significance. Biochimica et Biophysica Acta 1840 2491-2497. (doi:10.1016/j.bbagen.2014.04.015)

Lambaerts K, Wilcox-Adelman SA \& Zimmermann P 2009 The signaling mechanisms of syndecan heparan sulfate proteoglycans. Current Opinion in Cell Biology 21 662-669. (doi:10.1016/j.ceb.2009.05.002)

Lawrence TS, Ginzberg RD, Gilula NB \& Beers WH 1979 Hormonally induced cell shape changes in cultured rat ovarian granulosa cells. Journal of Cell Biology 80 21-36. (doi:10.1083/jcb.80.1.21)

Levallet J, Koskimies P, Rahman N \& Huhtaniemi I 2001 The promoter of murine follicle-stimulating hormone receptor: functional characterization and regulation by transcription factor steroidogenic factor 1. Journal of Molecular Endocrinology 15 80-92. (doi:10.1210/mend.15.1.0583)

Levallet G, Levallet J \& Bonnamy PJ 2007 Alterations in proteoglycan synthesis selectively impair FSH-induced particulate CAMPphosphodiesterase 4 (PDE4) activation in immature rat Sertoli cells. Biochimica et Biophysica Acta 1770 638-648. (doi:10.1016/j. bbagen.2006.12.006)

Levallet G, Levallet J \& Bonnamy PJ 2008 FSH-induced phosphoprotein phosphatase 2A-mediated deactivation of particulatephosphodiesterase-4 activities is abolished after alteration in proteoglycan synthesis in immature rat Sertoli cells. Journal of Endocrinology 197 45-54. (doi:10.1677/JOE-07-0497)

Levallet G, Bonnamy PJ \& Levallet J 2013 Alteration of cell membrane proteoglycans impairs FSH receptor/Gs coupling and ERK activation through PP2A-dependent mechanisms in immature rat Sertoli cells. Biochimica et Biophysica Acta 6 7. (doi:10.1016/j. bbagen.2013.02.027)

Luo W \& Wiltbank MC 2006 Distinct regulation by steroids of messenger RNAs for FSHR and CYP19A1 in bovine granulosa cells. Biology of Reproduction 75 217-225. (doi:10.1095/biolreprod.105.047407)

Mizutani T, Ju Y, Imamichi Y, Osaki T, Yazawa T, Kawabe S, Ishikane S, Matsumura T, Kanno M, Kamiki Y et al. 2014 C/EBPbeta (CCAAT/ enhancer-binding protein beta) mediates progesterone production through transcriptional regulation in co-operation with SF-1 (steroidogenic factor-1). Biochemical Journal 460 459-471. (doi:10.1042/BJ20131522)

Mizutani T, Ishikane S, Kawabe S, Umezawa A \& Miyamoto K 2015 Transcriptional regulation of genes related to progesterone production. Endocrine Journal 62 757-763. (doi:10.1507/endocrj.EJ15-0260)

Nishi Y, Yanase T, Mu Y, Oba K, Ichino I, Saito M, Nomura M, Mukasa C, Okabe T, Goto K et al. 2001 Establishment and characterization of a steroidogenic human granulosa-like tumor cell line, KGN, that expresses functional follicle-stimulating hormone receptor. Endocrinology 142 437-445. (doi:10.1210/endo.142.1.7862)

Oksjoki S, Sallinen S, Vuorio E \& Anttila L 1999 Cyclic expression of mRNA transcripts for connective tissue components in the mouse ovary. Molecular Human Reproduction 5 803-808. (doi:10.1093/ molehr/5.9.803)

Oktay K, Briggs D \& Gosden RG 1997 Ontogeny of follicle-stimulating hormone receptor gene expression in isolated human ovarian follicles. Journal of Clinical Endocrinology and Metabolism 82 3748-3751. (doi:10.1210/jcem.82.11.4346)

Owens GE, Keri RA \& Nilson JH 2002 Ovulatory surges of human CG prevent hormone-induced granulosa cell tumor formation leading to the identification of tumor-associated changes in the transcriptome. Journal of Molecular Endocrinology 16 1230-1242. (doi:10.1210/ mend.16.6.0850) 
Park JY, Richard F, Chun SY, Park JH, Law E, Horner K, Jin SL \& Conti M 2003 Phosphodiesterase regulation is critical for the differentiation and pattern of gene expression in granulosa cells of the ovarian follicle. Journal of Molecular Endocrinology 17 1117-1130. (doi:10.1210/ me.2002-0435)

Phamantu NT, Fagnen G, Godard F, Bocquet J \& Bonnamy PJ 1999 Sodium chlorate induces undersulfation of cellular proteoglycans and increases in FSH-stimulated estradiol production in immature rat Sertoli cells. Journal of Andrology 20 241-250. (doi:10.1002/j.1939-4640.1999. tb02515.x)

Price CA 2016 Mechanisms of fibroblast growth factor signaling in the ovarian follicle. Journal of Endocrinology 228 R31-R43. (doi:10.1530/ JOE-15-0414)

Princivalle M, Hasan S, Hosseini G \& de Agostini Al 2001 Anticoagulant heparan sulfate proteoglycans expression in the rat ovary peaks in preovulatory granulosa cells. Glycobiology 11 183-194. (doi:10.1093/ glycob/11.3.183)

Quirk SM, Cowan RG \& Harman RM 2004 Progesterone receptor and the cell cycle modulate apoptosis in granulosa cells. Endocrinology $\mathbf{1 4 5}$ 5033-5043. (doi:10.1210/en.2004-0140)

Rodgers RJ \& Irving-Rodgers HF 2010 The roles of the ovarian extracellular matrix in fertility. Society of Reproduction and Fertility supplement $\mathbf{6 7}$ 217-230.

Sasseville M, Albuz FK, Côté N, Guillemette C, Gilchrist RB \& Richard FJ 2009 Characterization of novel phosphodiesterases in the bovine ovarian follicle. Biology of Reproduction 81 415-425. (doi:10.1095/ biolreprod.108.074450)

Sato E, Miyamoto H \& Koide SS 1990 Glycosaminoglycans in porcine follicular fluid promoting viability of oocytes in culture. Molecular Reproduction and Development 26 391-397. (doi:10.1002/ mrd.1080260415)

Stewart MD \& Sanderson RD 2014 Heparan sulfate in the nucleus and its control of cellular functions. Matrix Biology 35 56-59. (doi:10.1016/j. matbio.2013.10.009)

Stocco C 2008 Aromatase expression in the ovary: hormonal and molecular regulation. Steroids 73 473-487. (doi:10.1016/j. steroids.2008.01.017)

Sugino N 2014 Molecular mechanisms of luteinization. Obstetrics and Gynecology Science 57 93-101. (doi:10.5468/ogs.2014.57.2.93)

Szatmari T \& Dobra K 2013 The role of syndecan-1 in cellular signaling and its effects on heparan sulfate biosynthesis in mesenchymal tumors. Frontiers in Oncology 3310.

Szatmari T, Mundt F, Heidari-Hamedani G, Zong F, Ferolla E, Alexeyenko A, Hjerpe A \& Dobra K 2012 Novel genes and pathways modulated by syndecan-1: implications for the proliferation and cell-cycle regulation of malignant mesothelioma cells. PLoS ONE 7 e48091. (doi:10.1371/ journal.pone.0048091)
Teng YH-F, Aquino RS \& Park PW 2012 Molecular functions of syndecan-1 in disease. Matrix Biology 31 3-16. (doi:10.1016/j.matbio.2011.10.001)

Thompson WJ \& Appleman MM 1971 Multiple cyclic nucleotide phosphodiesterase activities from rat brain. Biochemistry 10 311-316. (doi:10.1021/bi00778a018)

Tkachenko E, Rhodes JM \& Simons M 2005 Syndecans: new kids on the signaling block Circulation Research 96 488-500. (doi:10.1161/01. RES.0000159708.71142.c8)

Tsuiki A, Preyer J \& Hung TT 1988 Fibronectin and glycosaminoglycans in human preovulatory follicular fluid and their correlation to follicular maturation. Human Reproduction 3 425-429. (doi:10.1093/ oxfordjournals.humrep.a136721)

Tsutsumi R, Hiroi H, Momoeda M, Hosokawa Y, Nakazawa F, Koizumi M, Yano T, Tsutsumi O \& Taketani Y 2008 Inhibitory effects of cholesterol sulfate on progesterone production in human granulosa-like tumor cell line, KGN. Endocrine Journal 55 575-581. (doi:10.1507/endocrj.K07097)

Watson LN, Mottershead DG, Dunning KR, Robker RL, Gilchrist RB \& Russell DL 2012 Heparan sulfate proteoglycans regulate responses to oocyte paracrine signals in ovarian follicle morphogenesis. Endocrinology 153 4544-4555. (doi:10.1210/en.2012-1181)

Woodruff TK \& Shea LD 2011 A new hypothesis regarding ovarian follicle development: ovarian rigidity as a regulator of selection and health. Journal of Assisted Reproduction and Genetics 28 3-6. (doi:10.1007/ s10815-010-9478-4)

Yanagishita M, Hascall VC \& Rodbard D 1981 Biosynthesis of proteoglycans by rat granuloma cells cultured in vitro: modulation by gonadotropins, steroid hormones, prostaglandins, and a cyclic nucleotide. Endocrinology 109 1641-1649. (doi:10.1210/endo-109-5-1641)

Zong F, Fthenou E, Castro J, Peterfia B, Kovalszky I, Szilak L, Tzanakakis G \& Dobra K 2010 Effect of syndecan-1 overexpression on mesenchymal tumour cell proliferation with focus on different functional domains. Cell Proliferation 43 29-40. (doi:10.1111/j.1365-2184.2009.00651.x)

Zong F, Fthenou E, Mundt F, Szatmari T, Kovalszky I, Szilak L, Brodin D, Tzanakakis G, Hjerpe A \& Dobra K 2011 Specific syndecan-1 domains regulate mesenchymal tumor cell adhesion, motility and migration. PLoS ONE 6 e14816. (doi:10.1371/journal.pone.0014816)

Received 19 July 2016

First decision 17 August 2016

Revised manuscript received 17 March 2017

Accepted 27 March 2017 